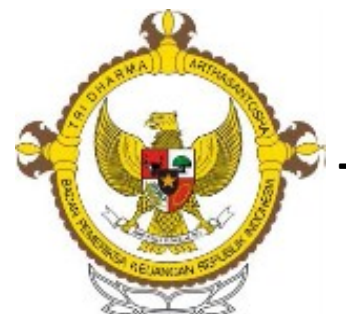

JURNAL

TATA KELOLA \& AKUNTABILITAS KEUANGAN NEGARA

e-ISSN 2549-452X

p-ISSN 2460-3937

\title{
SELF-EFFICACY AND CONTROLLABILITY AS WHISTLEBLOWING INTENTION PREDICTORS OF FINANCIAL MANAGERS IN EDUCATIONAL INSTITUTIONS
}

\author{
I Wayan Yeremia Natawibawa ${ }^{1}$, Gugus Irianto ${ }^{2}$, and Roekhudin ${ }^{3}$ \\ Faculty of Economics and Business, Brawijaya University, Jl. MT. Haryono 165 Malang \\ jerry_bali@yahoo.co.id ${ }^{1}$ \\ gugusir@ub.ac.id ${ }^{2}$ \\ roynajam@yahoo.com ${ }^{3}$
}

\begin{abstract}
Whistleblowing policy is considered as an effective technique in an investigation audit that is useful for the organization to avoid losses due to fraud. However, employees who intend to report fraud encounter ethical dilemma. Whistleblowing is a behavior that respects honesty, but is also a behavior that can possibly compromise organizational loyalty. The objective of this study is to analyze factors influencing whistleblowing intention of financial managers in school organization by understanding the action based on decomposed theory of planned behavior (DTPB). Data were collected through questionnaires that were distributed to financial managers of school organizations, particularly principals, vice-principals, administration heads, treasurers, and financial administration employees of public senior high schools, vocational high schools, and Islamic high schools in Malang City. Study population comprised of 214 persons. Response rate was $89.72 \%$, or there were 192 questionnaires that were duly completed. The analysis method employed was multiple regression. Two independent variables were observed in this study, namely self-efficacy and controllability, while only one dependent variable was examined, namely whistleblowing intention. Result of the study shows that self-efficacy and controllability have positive effect on whistleblowing intention, entailing that whistleblowing intention of employees will increase when they possess self-confidence and strong intention to conduct whistleblowing.
\end{abstract}

\section{KEYWORDS:}

self efficacy; controllability; whistleblowing intention 


\section{INTRODUCTION}

Potential abuse in financial management may arise in any organization, and educational institutions are not exempt. The Association of Certified Fraud Examiners (ACFE), an anti-fraud organization, disclosed in its Report to the Nation that education ranks sixth among the 23 sectors in terms of sectors with the most corruption cases, with 132 cases occurring in 2016. Of the 132 cases $34.1 \%$ involved billing, $13.6 \%$ involved cash larceny, $17.4 \%$ involved cash on hand, $7.6 \%$ were cases of check tampering, 31.8\% were cases corruption, $15.9 \%$ involved expense reimbursement, $5.3 \%$ were financial statement frauds, $17.4 \%$ were non-cash cases, $7.6 \%$ were payroll cases, $1.5 \%$ register disbursement cases, and 25\% skimming cases.

Fraud in financial management remain frequently occurring in Indonesia's education sector. Indonesia Corruption Watch (ICW), a non-governmental organization dedicating itself to monitor and report to the public corruption cases occurring in the country, reports that schools are educational institutions that are particularly prone to corruption. In the period between 2005 and 2016 there were 93 cases where education budget was abused by schools (CNN Indonesia, 2016). Loss incurred due to corruption in schools within such time span was as high as 136 billion Rupiah, with 65 principals and 27 school treasurers being named as suspects in graft probes (Koran Jakarta, 2018).

Lembaga Pendidikan and Pemberdayaan Kepala Sekolah (LPPKS) or the Indonesian Education and School Principal Empowerment Institution, of the Ministry of Education and Culture stated that there are three types of problem that often arises in a school's financial management. These problems include financial abuse by schools for self-enrichment, or what is known as corruption, significantly manipulated school financial reports, and improper spending of budgets, such as the misappropriation of funds intended for the procurement of books by the school manager (LPPKS, 2013). The top ten cases of corruption by object of corruption are presented in table 1 . The object most targeted for corruption are funds intended for rehabilitation and procurement of school facilities and infrastructure or madrasah (Islamic boarding schools). This is due to the significant size of the funds for such procurement, thus providing greater opportunities

Table 1. Corruption in Education by Object of Corruption

\begin{tabular}{|c|c|c|c|}
\hline No. & Object of Corruption (Top 10) & $\begin{array}{c}\text { Number of } \\
\text { Cases }\end{array}$ & $\begin{array}{l}\text { State's Losses } \\
\text { (Billions) }\end{array}$ \\
\hline 1. & $\begin{array}{l}\text { School/madrasah rehabilitation funds and facilities/ infra- } \\
\text { structure procurement }\end{array}$ & 47 & 115.9 \\
\hline 2. & School/madrasah operating funds & 33 & 12.8 \\
\hline 3. & Teacher salary/benefits & 12 & 11.0 \\
\hline 4. & School/madrasah construction/deconstruction & 12 & 10.9 \\
\hline 5. & School book/lesson books funds & 10 & 43.3 \\
\hline 6. & Block grants & 5 & 7.2 \\
\hline 7. & Scholarship funds & 5 & 3.5 \\
\hline 8. & Higher education operating funds & 2 & 6.4 \\
\hline 9. & Sub-national education funds (Porseni, teachers training) & 2 & 2.7 \\
\hline 10. & Salary taxes and teachers benefits & 1 & 23.0 \\
\hline
\end{tabular}

Source: Handayani (2009) 
for the offence to be committed (Handayani, 2009).

One issue or impediment in the effort to eradicate corruption in the education sector is that it is not easy to uncover instances of fraud in the financial management of education institutions. According to ICW's Public Service Monitoring Division Coordinator, corruption in schools is systemic. Corruption in school not only benefit the teachers and the school; there are many who stand to gain by concealing such practice. A hurdle that stems from the school's internals is its poor budgetary management (Indonesia Corruption Watch, 2010).

An effective means by which to uncover illegal activities within the organization is whistleblowing by staff members. Crook (2000) defines whistleblowing as an action by a staff member who discloses his/her concern relating to fraud, illegal conduct, or other unethical behaviour to a party outside the organization for reasons that prevent him/her from disclosing the issue internally. The $\mathrm{Na}$ tional Committee for Governance Policies, or Komite Nasional Kebijakan Governance (KNKG), defines whistleblowing as a disclosure of an offense or an unlawful, unethical/ immoral act, or other type of conduct that may adversely affect the organization or other stakeholders, committed by an employee or management of the organizations, to the organization's management or other institutions that can take action against the offense. The disclosure is usually made in confidence (Tuanakotta, 2010). Crook (2000) states that some fraud cases are able to be discovered through whistleblowing, as also stated by Suryono and Chariri (2016), who report that early detection of fraud will be more effective if the entity adopts a whistleblowing mechanism. Whistleblowing is an internal control mechanism to prevent violations within the organization and therefore plays a crucial role in encouraging any staff member who have knowledge of a fraud be- ing committed within the organization to disclose such offence (Zakaria, 2015).

Even though whistleblowing is seen as an effective tool in uncovering fraud within an organization, whistleblowing inherently gives rise to a dilemma. On the one hand, whistleblowing is an action that upholds honesty, but on the other hand it is conduct that can be considered as a disloyalty towards one's organization (Waytz et al., 2013). Some whistleblowing would be deemed as heroes, while others may have to face retaliation from their community, as whistleblowing is considered as a form of treachery (Waytz et al., 2013).

A whistleblower can become a target of retaliation from the organization's management, especially when the allegation that they communicate is found to be substantiated (Rothschild \& Miethe, 1999). A survey of 233 whistleblowers in the United Kingdom and the United states found that $84 \%$ of them lost their jobs within three months after they have exposed the occurrence of fraud within their organizations (Crook, 2000). Most of the whistleblowers had to endure adverse situations as a result of their action, namely retaliation, being shot at, duress and, oftentimes ostracism (Waytz et al., 2013). Not infrequently, whistleblowers who have brought the organization's deficiencies into light would have to deal with the resentment of their managers and would instead be made as the scapegoat and may have to bear the blame (Rothschild \& Miethe, 1999). A research conducted by Rothschild and Miethe (1999) has found that among the acts of retaliation suffered by whistleblowers from their supervisors or colleagues include loss of employment or forced retirement, receiving negative performance reviews, more severe scrutiny of their work by their supervisor, criticism from or avoidance by their peers, and blacklisted from receiving other tasks within their area of work. Another effect usually suffered by a whistleblower is severe 
depression or anxiety (84\%), feeling of isolation (84\%), distrust of others (78\%), deterioration of physical health (69\%), significant downturn of financial condition (66\%), and relationship issues with family (53\%) (Rothschild \& Miethe, 1999).

Given the fear for their personal safety and the safety of their family members and other kinds of risks faced by whistleblowers if they were to disclose fraud that occur at their workplace, the organization or agency would miss out on vital information that would otherwise allow the fraud to be discovered. Whistleblowing can be a dangerous endeavor for an employee who may be aware of a fraud, corruption, or illegal practice. They often fail to raise their concern of their workplace. An independent survey of 4,000 workers shows that $33 \%$ of the respondents have witnessed unethical conduct committed in their organization, $56 \%$ have heard of people lying to their supervisors, $41 \%$ have observed falsification in accounting, 35\% have witnessed theft, and $31 \%$ have seen drug and alcohol abuse. However, 54\% of employees who were aware of such malpractices did not make any report due to fear of reprisal (Crook, 2000).

With the dilemma faced by whistleblowers, it is important for an organization to establish a whistleblowing policy to gain an understanding of the factors that may affect the intention of its members to become whistleblowers. This should be achieved by referring to behavioral theories in order to ensure that the system and policies formulated can run effectively. A number of experts have developed useful behavioral theories to explain the actions and behavior of individuals along with their influencing factors, including a person's motivation to blow the whistle. A renowned figure in the development of behavioral theory in 1980 is Icek Ajzen known as the theory of reasoned action (TRA). TRA postulates that a behavior is created due to an individual's intention or desire to adopt a conduct a behavior. Behavior is a real action that is carried out. According to TRA, such behavioral intention is determined by attitude towards behavior and subjective norms. Attitude is an evaluation of belief or affect that may be positive or negative of an individual when he or she has to perform a particular intended behavior. Meanwhile, subjective norm is the perception of a person towards social pressure (belief of others) that would affect the intention to perform or not to perform a behavior being contemplated (Jogiyanto, 2007).

Upon further development of the theory, Ajzen (1991) developed the TRA by adding a perceived behavioral control (PBC), as a determinant of the behavioral intent, into the model. Perceived behavioral control is defined as an individual's perception on the ease or difficulty by which to perform a behavior. Perceived behavioral control is reflected by past experiences and resource availability, such as funds, expertise, time, collaboration with other parties, and existing opportunities. According to Ajzen (1991), intention to manifest a behavior can be predicted with reasonably high accuracy through attitude toward behavior, subjective norms, and perceived behavior control. The more attracted attitude and subjective norm are towards a behavior, and the larger the perceived behavioral control, then the stronger a person's intention to perform the contemplated behavior. This theory developed by Aijzen (1991) is called the theory of planned behavior (TPB). The theory constitute an extension of TRA make up for the limitation of the original model with respect to behavior whereby a person has incomplete control over his or her intention. In other words, a person believes on the existence of factors that can drive or impede the performance of a behavior. As in the TRA, the central factor in TPB is the individual's intention to perform a certain behavior. Intention is assumed to be a motivational factor that influences behavior that indicates how hard a 
person's effort is to perform a behavior (Ajzen, 1991). A person who believes that he or she does not possess the resources or opportunity to perform a behavior is in a condition that would not form a strong behavioral intention (Jogiyanto, 2007).

In 2002, Ajzen decomposed perceived behavioral control variable into two subvariables, namely self-efficacy and perceived controllability. This theory is known as decomposed theory of planned behavior (DTPB). Self-efficacy, sometimes also referred to as belief in one's self, relates to the ease or difficulty by which to perform a behavior (Ajzen, 2002). On the other hand, controllability constitute the belief of other people that they have control over such behavior, i.e. the performance or nonperformance of such behavior is reliant upon them (Ajzen, 2002).

Some researchers use variables that are existing within the DTPB to test factors that influence a person's intention to become a whistleblower. A number of researchers have studied the effect of self-efficacy on the intention to report a wrongdoing. Research conducted by Wei et al. (2016), Sharif (2015), MacNab and Worthley (2008), as well as Sama (2014) have found that selfefficacy has an impact on a person's intention to become a whistleblower. However, a study conducted by Hartono and Cahaya (2017) has found that self-efficacy shows no effect on the intention to blow the whistle. Hartono and Cahaya (2017), who observed civil servants working at the police office in the Special Region of Yogyakarta (DIY), argue that to address corruption, efforts should not only rely on one's personal capability, but should be undertaken collaboratively with the support of the entire society. Orhan and Ozyer (2016), who studied students in Turkey, opine that from a cultural perspective in Turkey, whistleblowing constitutes an objectionable action. A person with high selfefficacy would not seek to be involved in whistleblowing, as such action would expose negative situation. Exposure of a negative occurrence within the company would bring about negative consequences.

Some researchers have also studied the effect of controllability on intention to blow the whistle, such as Curtis and Taylor (2009), Chiu (2002), Fitriyah and Nagara (2017), Ahmad (2011), Ghani (2013), and Ahmad et al. (2012). The study by Curtis and Taylor (2009) established that controllability has an effect on intention to blow the whistle. Findings from research by Chiu (2002) proves that controllability moderates the relationship between ethical evaluation and the intention to blow the whistle. Results from studies conducted by Fitriyah and Nagara (2017), Ahmad (2011), Ghani (2013), and Ahmad et al. (2012) find that controllability does not bear influence on the intention to blow the whistle. According to Ahmad et al. (2012), when a situation is not under the control of the person, this would not affect his or her decision whether or not to blow the whistle.

It was found in earlier studies that reports from studies are still not unanimous on this matter. A number of studies have successfully proven DTPB as a predictor of an individual's intention to blow the whistle, but other studies have found that DTPB cannot serve as such predictor. The present study aims to retest the variables embodied in DTPB, namely efficacy and controllability of intention to blow the whistle using financial managers in public high schools/Islamic high schools/vocational schools throughout Malang City, comprising of their principal, vice principal, head of administrative affairs department, school treasury, and financial administration staff as respondents.

In the management of their finances, schools adopt implements a separation of duties among the authorizer, chief accountant, and treasurer (Mulyasa, 2009). The authorizer is 
the official conferred with the authority to exercise actions that generate income and expenditure of budget. The chief accountant is the official with the authority to test and instruct payment for any action carried out based on the affirmed authority. The principal plays a role in overseeing the schools finances and the authorizer, and is delegated with the functions of a chief accountant to instruct payment. The principal, however, is not allowed to undertake a treasurer's functions as he or she has the obligation to effect internal supervision (Mulyasa, 2009). Further, one responsibility of the head of the administration department pursuant to the Decrees of the Director General of Elementary and Secondary Education (Dirjen Dikdasmen) No. 260 and 261 of 1996 is to be accountable for the management of school finances. The treasurer is the official authorized to receive, maintain, and spend monies or other negotiable documents and are required to prepare calculations and accountability reports (Mulyasa, 2009). The primary duties of a school's treasurer under the LPPKS is to handle the schools financial administration including its routine financial affairs/UYHD (money that must be accounted for)/BOPS (School Library Operational Assistance), Dana BOS (School Operating Assistance Funds), school committee funds, and funds from other sources. The treasurer directly reports to the head of the administration department. The school's treasurer, aside from being assigned with treasury duties, is also assigned with the functions of a chief accountant to validate entitlement to payment (Mulyasa, 2009). With the organizational structure of large schools, the school's treasurer may be assisted by several financial staff members to ensure the effective management of the schools finances.

The present study takes as its research subject high schools and high school equivalents, as they are provided with more facilities compared to junior high schools and elementary schools or their equivalents, as sti- pulated under Regulation of the Minister of Education Number 24 of 2007. This is consistent with the fact presented by Handayani (2009) that rehabilitation funds and facility and infrastructure budget of schools/Islamic boarding schools are objects that are most frequently targeted for corruption.

\section{RESEARCH METHOD}

\section{Population and Sampling Methods}

The population of the present research is the entire financial managers of schools, including the principal, vice principal, head of administration department, school treasurer, and financial administrators in public high schools, Islamic high schools, and vocational schools in Malang City, comprising of 214 respondents. All members of the population are used as samples.

The present research is a causal study, namely one which explains the presence or lack of influence from an independent variable on a dependent variable (Sekaran, 2013). The research elaborates the influences of independent variables, namely self-efficacy and controllability on a dependent variable, namely whistleblowing intention. Data used in this research are primary data derived from questionnaire responses.

\section{Variables and Measuring of Variables}

The present research features two independent variables, namely self-efficacy and controllability, and one dependent variable, which is the intention to uncover fraud or whistleblowing intention.

Belief in one's self or self-efficacy is defined as the ease or difficulty by which a person performs a behavior (Ajzen, 2002). The present research utilizes the variable of self- 
efficacy based upon the concept put forward by Sharif (2015), MacNab and Worthley (2008), also Hsu and Chiu (2004). Measurement of self-efficacy as a variable indicator uses the five-point Likert-type scale, namely 'strongly disagree' (STS), 'disagree' (TS), 'neutral' (N), 'agree' (S), and 'strongly agree' (SS). The indicators established by Sharif (2015) are:

1. Ability to report fraud/violation.

2. Conviction that one is able to report fraud/violation despite advise from a friend to refrain from doing so.

3. Conviction that one can report fraud/ violation despite being in a situation that impede people from doing so.

4. Conviction that one can report fraud/ violation despite the management team is against such course of action.

The indicator according to the concept put forward by MacNab and Worthley (2008) is to figure out a solution when a problem arises. Indicators based on the concept of Hsu and Chiu (2004) are:

1. If there is willingness, reporting a violation (whistleblowing) is easy to do.

2. For me, reporting a violation (whistleblowing) is easy.

3. There are many things that create a conviction of one's ability to report a violation (whistleblowing).

4. Assumption that I am always able to report a violation (whistleblowing).

5. If it is up to myself, I am convinced that I will be able to report a violation (whistleblowing).

6. If one is willing to try, one would tend to be able to report a violation (whistleblowing) immediately.

Controllability involves people's belief that they have control over such behavior; that to perform or not to perform a behavior is dependent on their will (Ajzen, 2002). The present research uses the variable of controllability based upon the concept of Curtis and Taylor (2009), Ahmad (2011), and Hsu and Chiu (2004). Measuring the variable indicator of controllability is by using the fivepoint Likert-type scale, namely 'strongly disagree' (STS), 'disagree' (TS), 'neutral' (N), 'agree' (S), and 'strongly agree' (SS). The indicators established by Curtis and Taylor (2009) are:

1. A work is something that is performed.

2. In various work, a person can achieve what they want to achieve.

3. If one knows what one wants to achieve from a work, that he or she can find work that provides what they want.

4. An employee that is not satisfied with the decision of the management would feel that they need to do something.

5. Finding a work that is desired is a matter of luck.

6. Many people are capable of doing their job if they are willing to put effort into it.

7. Promotion relates to luck.

Indicators according to Ahmad (2011) are:

1. Earning money is a matter of luck.

2. Many people are capable of performing their work if they are willing to try.

3. In order to get a good job, one needs to have a family member or friend holding a high position.

4. Promotion is given to employees with good work performance.

Indicators according to Hsu and Chiu (2004) are:

1. Large number of controls.

2. Full control. 
3. It is up to one's self whether to control one's action.

4. A strong capability to control one's actions.

5. Very few events that cannot be controlled which impedes the carrying out of action.

The dependent variable presented in this study is whistleblowing intention. Intention is defined as a desire to perform a behavior, while behavior is an actual action performed (Jogiyanto, 2007). Therefore, whistleblowing intention is the intention to disclose fraud/ violation within the organization to a person capable of exercising corrective actions with respect to such fraud/violation. The study uses the whistleblowing intention variable based on the concept put forward by Poespito (2017), Bagustianto and Nurkholis (2014), and Park and Blenkinsop (2009). The indicators according to Poespito (2017) are:

1. I fell proud when I am able to report a fraud/violation that I actually witness and is substantiated.

2. I am interested to become a person who is capable of reporting and proving a fraud/ violation that I actually witness and is substantiated.

3. I want to be involved as a whistleblower, namely a person who will not stand for fraud and therefore wants to report such offense in order for the situation to be resolved.

Indicators according to Bagustianto and Nurkholis (2014) are:

1. The intention to blow the whistle.

2. The desire to try to blow the whistle.

3. A plan to blow the whistle.

4. Great effort to conduct internal whistleblowing.

5. Great effort to conduct external.
Indicators according to Park and Blenkinsop (2009) are:

1. Will report the violation to the responsible authority outside the organization.

2. Will use a reporting channel outside the organization.

3. Will inform an external agency regarding the fraud/violation.

4. Will inform the public regarding the fraud/violation.

5. Will report the fraud/violation to the appropriate person within the organization.

6. Will make use of the appropriate reporting channels for fraud/violation within the organization.

7. Will report the fraud/violation to upper management.

8. Will inform his/her direct supervisor regarding the fraud/violation.

The study employs multiple linear regression to identify the link between the independent variables and the dependent variable. The author conduct statistical analysis with the help of the SPSS statistics software version 24. The general model for the regression equation can be formulated as follows:

$$
Y=\alpha+\beta_{1} X_{1}+\beta_{2} X_{2}+\varepsilon
$$

Note:

$\begin{array}{lll}\mathrm{Y} & = & \text { Whistleblowing Intention } \\ \alpha & = & \text { Constant } \\ \mathrm{X} 1 & = & \text { Self Efficacy } \\ \mathrm{X} 2 & = & \text { Controllability } \\ \varepsilon & = & \text { Error }\end{array}$

The regression analysis performed would yield $\alpha$ and $\beta$ values that would complement the regression model mathematical equation above. Prior to the analysis, a reliability and 
validity test is conducted using the SPSS statistics software version 24 .

- A variable is considered as reliable if it provides a value of Cronbach Alpha > 0.70 (Nunnally, 1994 in Ghozali, 2016).

- Validity test is performed using Confirmatory Factor Analysis (CFA). The Confirmatory Factor Analysis is used to test whether a variable has unidimensionality or whether the indicators used can conform a variable (Ghozali, 2016). The testing tool used to measure the extent of intercorrelation between the variables and whether or not a Kaiser-Meyer-Olkin Measure of Sampling Adequacy (KMO MSA) factor analysis can be performed. The expected value should be $>0,50$.

Following the validity and reliability test, a regression analysis can be performed.

\section{Classical Assumption Test}

Following a multiple linear regression analysis is performed that yields a regression equation model, the next step would be to conduct a classical assumption test. The classical assumption test is aimed to provide a certainty that the regression equation obtained possess accuracy in its estimate, is not biased, and is consistent. Some classical assumption tests are as follows:

\section{Multicollinearity Test}

A multicollinearity test is intended to test whether in a regression model there is found a correlation among independent variables. A good regression model should lack any correlation between its independent variables (Ghozali, 2016). Multicollinearity can be seen from (1) tolerance and its opposite, and (2) variance inflation factor (VIF). Both of these measurements show which individual independent variable is explained by the other variables. In simple terms, which individual independent variable is explained by the other independent variables. In simple terms, each independent variable becomes a dependent (bound) variable and digress from the other independent variable. Tolerance measures the variability of the selected independent variable that is not explained by the other independent variables. As such a low tolerance value means a high VIF value (as VIF $=1 /$ Tolerance) . The cutoff value generally used to indicate multicollinearity is the a value of tolerance of $\leq 0.10$ or equal to a VIF value of $\geq 10$ (Ghozali, 2016).

\section{Heteroscedasticity test}

Heteroscedasticity test has the purpose of testing whether in a regression model there is a variance inconsistency of the residuals of one observation with another. If the variance of the residual of one observation with that of another is constant, such condition is known as homoscedasticity, whereas if they are different it is called heteroscedasticity. A good regression model is one which is homoscedastic, or where heteroscedasticity does not occur (Ghozali, 2016). Detection of heteroscedasticity can be done by looking whether there is a certain pattern in the SRESID and ZPRED scatterplot graphs, where the $\mathrm{Y}$ axis and predicted $\mathrm{Y}$ axis, and the $\mathrm{X}$ axis is the residual ( $\mathrm{Y}$ predicted $-\mathrm{Y}$ actual) which has been 'studenttized' (Ghozali, 2016). The basis of this analysis is that if there is a certain patter, such as points that form a certain regular pattern (wavy, expanding then contracting), then it would indicate that heteroscedasticity has occurred. If there does not exist a clear pattern, and the points are spread above and below $\mathrm{O}$ at the $\mathrm{Y}$ axis, then heteroscedasticity has not occurred (Ghozali, 2016). 


\begin{tabular}{rlr}
\hline \multicolumn{2}{l}{ Table 2. } & Distribution and Return of Questionnaires \\
\hline No. & \multicolumn{1}{c}{ Process } & Total \\
\hline 1. & Number of questionnaires distributed & 214 copies \\
\hline 2. & Number of questionnaires returned & 192 copies \\
\hline 3. & Number of incomplete questionnaires & 0 copies \\
\hline 4. & Number of questionnaires used for the study & 192 copies \\
\hline 5. & Response rate & $89.72 \%$ \\
\hline 6. & Response rate of questionnaires usable for the study & $89.72 \%$ \\
\hline
\end{tabular}

Source: Author's data processing and analysis

\section{Normality Test}

Normality test is intended to test whether in a regression model the distorter variables or residuals have a normal distribu- tion (Ghozali, 2016). One way to look at normality of residuals is to look at the histogram graph that compares between the observed data and the distribution that comes close to the normal distribution

Table 3. Respondents Profile

\begin{tabular}{|c|c|c|c|c|}
\hline No. & Item & Description & Number & Percentage \\
\hline \multirow[t]{6}{*}{1.} & Position & Principal & 19 & $9.90 \%$ \\
\hline & & Vice President & 87 & $45.31 \%$ \\
\hline & & Head of Administration Unit & 29 & $15.10 \%$ \\
\hline & & School Treasurer & 22 & $11.46 \%$ \\
\hline & & Financial Administrative Staff & 35 & $18.23 \%$ \\
\hline & & Total & 192 & $100 \%$ \\
\hline \multirow[t]{3}{*}{2.} & Sex & Male & 85 & $44.27 \%$ \\
\hline & & Female & 107 & $55.73 \%$ \\
\hline & & Total & 192 & $100 \%$ \\
\hline \multirow[t]{4}{*}{3.} & Age & $<30$ years old & 15 & $7.81 \%$ \\
\hline & & $30-40$ years old & 48 & $25 \%$ \\
\hline & & $>40$ years old & 129 & $67.19 \%$ \\
\hline & & Total & 192 & $100 \%$ \\
\hline \multirow[t]{5}{*}{4.} & Length of Service With- & $<3$ years & 15 & $7.81 \%$ \\
\hline & in the Organization & $3-5$ years & 19 & $9.90 \%$ \\
\hline & & $6-10$ years & 45 & $23.44 \%$ \\
\hline & & $>10$ years & 113 & $58.85 \%$ \\
\hline & & Total & 192 & $100 \%$ \\
\hline & Latest Education & SMA/MA/SMK & 18 & $9.38 \%$ \\
\hline & & Diploma 1 & 2 & $1.04 \%$ \\
\hline & & Diploma 2 & 1 & $0.52 \%$ \\
\hline & & Diploma 3 / Sarjana Muda & 14 & $7.29 \%$ \\
\hline & & Diploma 4 / Undergraduate & 104 & $54.17 \%$ \\
\hline & & Graduate & 48 & $25 \%$ \\
\hline & & Post-Graduate & 5 & $2.60 \%$ \\
\hline & & Total & 192 & $100 \%$ \\
\hline
\end{tabular}

Source: Author's data processing and analysis 
(Ghozali, 2016). A more reliable method is by looking at the normal probability plot that compares cumulative distributions of a normal distribution. A normal distribution would form a straight diagonal line, and plotting of residual data would then be compared with the diagonal land. If the residual data distribution is normal, then the line that represents the actual data would follow the diagonal line (Ghozali, 2016). If data is spread around the diagonal line and follows the direction of that line or if the histogram graph shows a normal distribution pattern, then the regression model meets the assumed normality. If data is spread far from the diagonal land and/or do not follow the direction of the diagonal line or the histogram graph does not show a normal distribution pattern, then the regression model fails to meet the assumed normality (Ghozali, 2016).

\section{Hypothesis Test}

Hypothesis test in this study is done by looking at the $t$ value. Statistic hypothesis can be formulated as follows:

1. First hypothesis testing

H1: Effect of self-efficacy on whistleblowing intention

Ho: $\beta 1 \leq 0$ means that self-efficacy does not positively influence whistleblowing intention

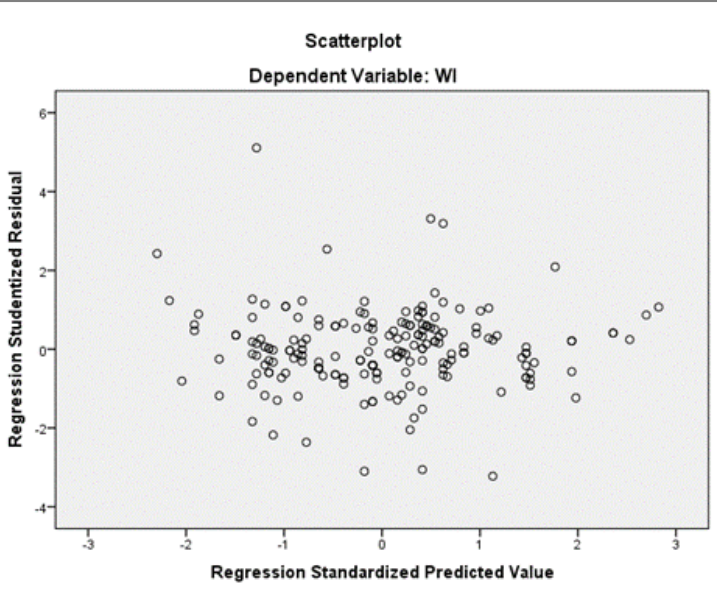

Figure 1. Heteroscedasticity Test Source: Author's data processing and analysis

Ho: $\beta 1>0$ means that self-efficacy positively influences whistleblowing intention

Ho is rejected when test result shows that $t \leq \alpha$ (0.05), thus it can be concluded that there is positive influence rendered by self -efficacy on whistleblowing intention.

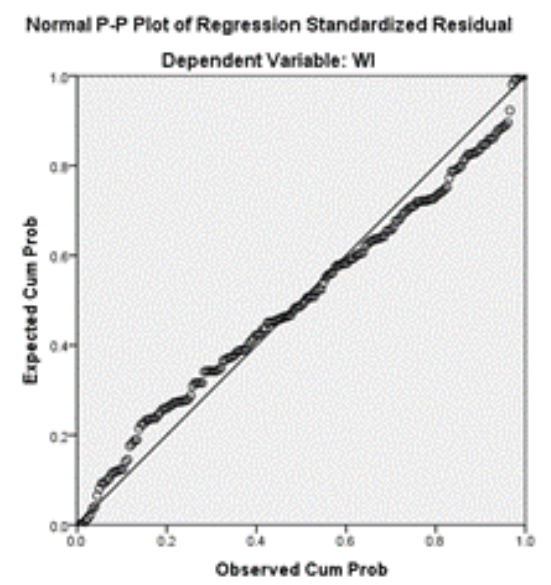

Figure 2. Normality Test

Source: Author's data processing and analysis

Table 4. Multicollinearity Test

\begin{tabular}{|c|c|c|c|c|c|c|c|}
\hline \multirow{2}{*}{ Model } & \multicolumn{2}{|c|}{$\begin{array}{l}\text { Unstandardized } \\
\text { Coefficients }\end{array}$} & \multirow{2}{*}{$\begin{array}{c}\text { Standardized } \\
\text { Coefficients } \\
\text { Beta }\end{array}$} & \multirow{2}{*}{$\mathbf{T}$} & \multirow{2}{*}{ Sig. } & \multirow{2}{*}{$\begin{array}{l}\text { Collinearity } \\
\text { Tolerance }\end{array}$} & \multirow{2}{*}{$\begin{array}{c}\text { VIF } \\
\text { Statistics }\end{array}$} \\
\hline & B & $\begin{array}{c}\text { Standard } \\
\text { Error }\end{array}$ & & & & & \\
\hline Constant & 6.953 & 4.639 & & 1.499 & 0.136 & & \\
\hline Self-Efficacy & 0.813 & 0.081 & 0.598 & 9.989 & 0.000 & 0.748 & 1.338 \\
\hline Controllability & 0.271 & 0.093 & 0.174 & 2.906 & 0.004 & 0.748 & 1.338 \\
\hline
\end{tabular}

Source: Author's data processing and analysis 
2. Second hypothesis testing

H2: The effect of controllability on whistleblowing intention

Ho: $\beta 2 \leq$ o means that controllability does not positively influence whistleblowing intention

Ho: $\beta 2>$ o means that controllability positively influences whistleblowing intention

Ho is rejected when test result shows that $\mathrm{t} \leq \alpha$ (0.05), thus it can be concluded that there is positive influence rendered by controllability on whistleblowing intention.

\section{RESULT AND DISCUSSION}

A total of 214 questionnaires were distributed to respondents in 25 schools between April 2018 and May 2018. Distribution and return rate of questionnaires is presented in table 2. A questionnaire return rate of 89.72\% constituted a good return rate as it was higher than $50 \%$, and the returned questionnaires were fully completed by the respondents. An overview of respondents is presented in table 3 . In table 3 it can be clearly seen that largest group of respondents in terms of position are principals and vice principals, totaling 106 people or $55.21 \%$ of the total 192 respondents. As such, respondents in this study are dominated by officials in charge of a schools finances carrying out
Table 6. Determination Coefficient

\begin{tabular}{cccc}
\hline R & R Square & $\begin{array}{c}\text { Adjusted R } \\
\text { Square }\end{array}$ & $\begin{array}{c}\text { Standard Error } \\
\text { of the Estimate }\end{array}$ \\
\hline 0.702 & 0.493 & 0.488 & 6.52876 \\
\hline
\end{tabular}

Source: Author's data processing and analysis

the tasks of authorizers and chief accountants. The majority of respondents in this study have more 10 years of service. In terms of the age and service period of the respondents, a majority of them are significantly experienced in their area of work. By education, the respondents of this study mostly hold a bachelors degree, or a total of 104 people representing $54.17 \%$ of respondents. The group with the second highest total are those with a graduate degree (S2), totaling 48 respondents or $25 \%$. Respondents with degrees ranging from Diploma 1 to $\mathrm{PhD}$ total 174 people or $90.62 \%$. It can be concluded that the majority of respondents in this study are of high education background. The quality of education of the human resources is a material aspect that determine the quality of a school as an educational institution.

\section{Result of Classical Assumption Test}

\section{Multicollinearity Test}

The multicollinearity test is presented in table 4 . The result of such test indicates that there is no multicollinearity in the regression model. In table 4 it is apparent that the tolerance value of the two independent variables, namely self-efficacy and controllability, are not lower than 0.10 , meaning that there is no correlation

Table 5. Multiple Regression Test

\begin{tabular}{cccccc}
\hline & \multicolumn{2}{c}{ Unstandardized Coefficients } & Standardized & T & Sig. \\
\cline { 2 - 5 } Model & B & Standard Error & Coefficients Beta & & 0.136 \\
\hline Constant & 6.953 & 4.639 & 0.598 & 9.999 & 0.000 \\
\hline Self-Efficacy & 0.813 & 0.081 & 0.174 & 2.906 & 0.004 \\
\hline Controllability & 0.271 & 0.093 & & 0.989 \\
\hline
\end{tabular}

Source: Author's data processing and analysis 


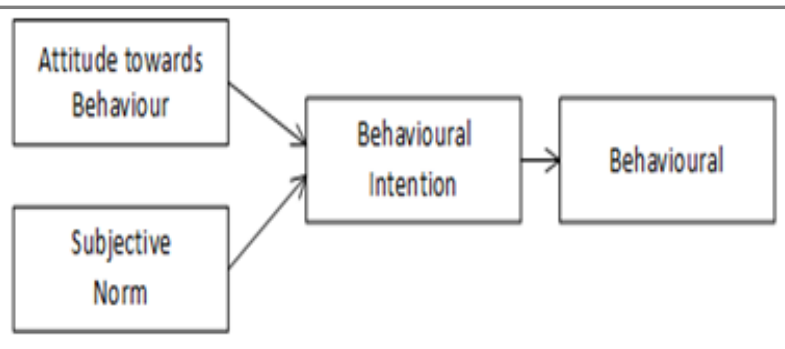

Figure 3. Theory of Reasoned Action Source: Jogiyanto (2007)

among independent variables whose value are more than $95 \%$. Result of calculation of Variance Inflation Factor (VIF) value also indicates that there is no single independent variable that has a VIF value of more than 10. As such it can be concluded that there exists no multicollinearity among the independent variables in the regression model.

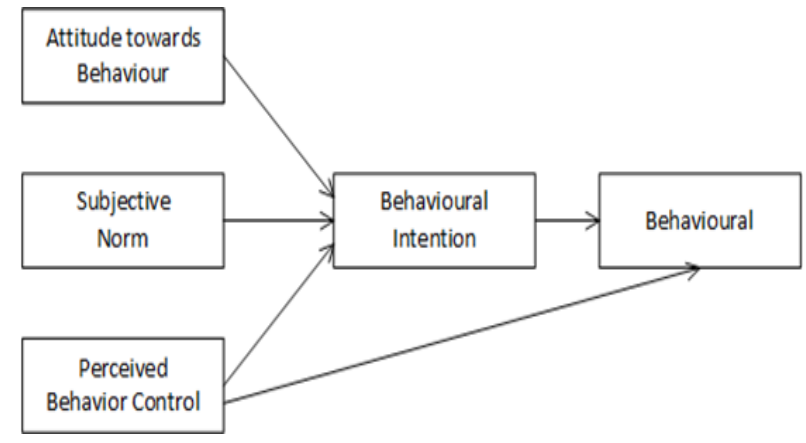

Figure 4. Theory of Planned Behavior Source: Jogiyanto (2007)

\section{Heteroscedasticity Test}

Heteroscedasticity test is presented in figure 1. The scatterplot graph shows that the points are spread randomly above and below $\mathrm{O}$ at the $\mathrm{Y}$ axis. The test result shows that there is no heteroscedasticity in the regression model.

\section{Normality Test}

Normality test is presented in figure 2 . Data as presented in figure 2 appears to be spread along the diagonal line and follows the direction of the diagonal line. Those indicates that the normality assumption has been satisfied.

\section{Result of Hypothesis Test}

The result of multiple linear regression analysis is presented in table 5. The first hypothesis postulates that self-efficacy has positive influence on whistleblowing intention. Significance value below $5 \%$ is 0.000 and coefficient with a positive value, and thus the first hypothesis is accepted.

The second hypothesis postulates that controllability has positive influence on whistleblowing intention. The hypothesis can be supported if the coefficient is of positive value with a significance value below $5 \%$. Significance value is below $5 \%$, namely 0.004 and coefficient is of a positive value, and as such the second hypothesis is accepted. It can be seen in table 5 that the largest standardized beta coefficient value is 0.598 . This shows that the independent variable of selfefficacy constitute an independent variable with dominant influence on whistleblowing intention.

Table 6 shows that the magnitude of adjusted $\mathrm{R}^{2}$ is 0.488 , meaning that $48.8 \%$ variations of whistleblowing intention can be explained by variations of the two independent variables, namely self-efficacy and controllability. The remaining $51.2 \%$ is explained by other causes outside the model.

In the theory of reasoned action (TRA), an actual course of action taken by a person can be predicted from his or her prior intention towards such behavior, thus the person's intention has an important role in the manifestation of an individual's behavior. The positive or negative outlook of an individual towards a behavior and the individual's perception towards such behavior do not necessarily impact directly on the individual's actual conduct, but they do, however, have a direct impact on their intention to perform a behavior that ultimately would affect the actual action of the individual. Figure 3 shows TRA as developed by Ajzen (1980). Further, 
Ajzen (1991) renewed the theory and thus TRA has developed into the theory of planned behavior (TPB). A new element in TPB is the introduction of a new variable, namely perceived behavioral control (PBC). Ajzen (1991) is of the view that a person's desire to perform a certain behavior and their actual actions are affected by individual perceptions on the ease or difficulty by which to perform a behavior, as reflected by desires in the past and availability of resources.

Figure 4 illustrates TPB as developed by Ajzen (1991). Ajzen (2002) further decomposed PBC into self-efficacy and controllability, making Ajzen's (2002) theory to be known as decomposed theory of planned behavior (DTPB). These two variables in the decomposed theory of planned behavior are believed to be the determinant of a person's intention to perform a behavior. In accordance with the general rule as prescribed by Ajzen (2002) on the theory of planned behavior, the higher the control of perceived behavior that constitute the master variable of the two sub-variables, namely self-efficacy and controllability, the stronger the individual's intention to perform a behavior. In the case of whistleblowing, self-efficacy and controllability are proven to be able to affect the intention of financial managers in schools to disclose violations. The effectiveness of policies and whistleblowing system is closely linked with self-efficacy and controllability possessed by the potential whistleblower.

Self-efficacy, or the belief a person has in his/her ability to perform a behavior, has a positive impact on the intention to become a whistleblower. The stronger the belief of such person his or her ability to perform a certain behavior, the higher their intention to perform such behavior. The result of this study is consistent with the result of the study conducted by MacNab and Worthley (2008), Sharif (2015), and Wei et al. (2016). Self-efficacy refers to the belief subscribed by a person of his or her ability to achieve a be- havior (Wei et al., 2016). Individuals with high self-efficacy have a larger tendency to refuse gifts, demonstrate a stronger commitment, are more diligent and effective in developing solutions to problems and plot strategies (MacNab \& Worthley, 2008). The present study shares similar results as the study conducted by Sharif (2015) in proving that self-efficacy is a major contributor to whistleblowing intention. MacNab and Worthley (2008) who conducted a study on professionals in Canada and the United States report that high self-efficacy will be able to affect the willingness and consistency of a person to become a whistleblower. Sama (2014) also stipulated that self-efficacy constitute one of the main variables in whistleblowing.

With regard to the link between self-efficacy and whistleblowing, self-efficacy would enable a person to be resilient in difficult situations that can potentially create stress that are associated with the act of whistleblowing (MacNab \& Worthley, 2008). A number of surveys have established that there are adverse effects experienced by whistleblowers as a consequence of their action. Most of them have found themselves in extremely difficult situations. With people with particularly low self-efficacy, the feeling of inability within one's self to deal with the risk of whistleblowing would be stronger. This condition can result in the low intention of such individual to blow the whistle in the first place. Conviction to carry out an action will increase if the individual's perception of the risk arising from such action is reduced.

Policymakers and whistleblowing systems need to reinforce the conviction of potential whistleblowers regarding the importance of whistleblowing policies and systems within educational institutions, namely to prevent material loss as a result of irregularities in the management of the school's finances. To develop the self-confidence of employees for doing whistleblowing action, they need to be 
informed of procedures in place that provide protection to whistleblowers. Crook (2000) stipulates that employees often are aware of a wrongdoing occurring within their organizations, but are reluctant to report such violation due to fear of being victimized because their disclosure of the incident. This indicates that individuals need to have a strong self-conviction that he or she can blow the whistle or disclose a wrongdoing within their organization without having to feel fear. The makers of whistleblowing policies can build the confidence of members of their organization to perform whistleblowing responsibly, namely by designing a whistleblowing system that can guarantee the security and anonymity of the informant. If such features are in place, the whistleblower can have the selfconfidence to present evidence of fraud that may be happening within the organization through the whistleblowing system provided without any fear of possible reprisal.

Controllability has the meaning of a belief or perception as to what extent a behavior is performed by one's own free will. Controllability has a positive impact on the intention to blow the whistle. The stronger the willingness or awareness of a person towards a behavior, the stronger the intention to perform such behavior. The result of the present study is consistent with Curtis and Taylor (2009) who studied auditors and proved that controllability fully affects whistleblowing intention. Policymakers and whistleblowing systems of schools need to raise the awareness of people within their organizations in order for them to give their attention to the state of their institution. The attention shown by people to their organization would make them more sensitive to indications of irregularities in the financial management of the organization. They will have awareness of the importance of implementing whistleblowing policies and system effectively.

One of the means that can be pursued to build employees' awareness is to assign them responsibility or give them trust, such as involving workers in the preparation of the organization's strategies or vision and mission. Lack of employees concern to their environment would have the effect of increasing the possibility of fraud occurring in the organization's financial management. If a person cares about his or her organization, then such person would also continually strives to assist the organization to achieve its vision and mission and ensure that it avoids losses, which among others are caused by fraud in financial management.

The makers of whistleblowing system and policies in schools need to raise the awareness of employees on the importance of having a whistleblowing system and policies in place as a tool to prevent the organization suffering loss due to fraud. As stipulated by Winardi (2013), low level employees within government institutions are potential whistleblowers as they are actively involved in the operational and technical activities. Winardi (2013) postulates that employees have detailed knowledge on how their organization works and they are the people that are most likely to uncover corruption at their workplace. To raise the awareness of school employees on the importance of having a whistleblowing system and policy in their organization, persons in charge of preparing whistleblowing systems and policies need to educate employees on the importance of having such system and policies as a form of internal control to avoid loss caused by fraud.

The result of this study is useful for developing a behavior theory, namely the decomposed theory of planned behavior to be used as a predictor of whistleblowing intention among financial managers in educational institutions. Whistleblowing policies constitute a way to implement organizational governance and is also a form of investigative audit designed by the organization to prevent loss due to fraud in educational institutions. This study has proven that decom- 
posed theory of planned behavior can be taken into consideration as a means to enhance the effectiveness of whistleblowing policy in schools. The two variables present in the decomposed theory of planned behavior, namely self-efficacy and controllability, are important variables to be used as predictors of whistleblowing intention by the makers of whistleblowing system and policy in schools to allow such system and policy to function effectively.

\section{CONCLUSION}

This study has found that both of the variables in the decomposed theory of planned, namely self-efficacy and controllability, have a positive influence on the whistleblowing intention of financial administrators in schools. The higher the self-efficacy and controllability of an employee, therefore the intention of such employee to blow the whistle is also stronger. As such, the makers of whistleblowing policies need to pay attention to two elements when designing such system and policy, namely self-confidence and awareness of employees on the importance of having a whistleblowing system and policy in place to allow such system and policies to function effectively.

\section{REFERENCES}

Ahmad, S. A. (2011). Internal auditor and internal whistleblowing intentions: a study of Organisational, Individual, Situational and demographic factors. (Theses). School of Business and Law, Edith Cowan University, West Australia. Retrieved from https:// ro.ecu.edu.au/theses/152.
Ahmad, S., Smith, G., \& Ismail, Z. (2012). Internal whistle-blowing intentions: a study of demographic and individual factors. Journal of Modern Accounting and Auditing, 8(11), 1632 - 1645.

Ajzen, I. (1991). The theory of planned behavior. Organizational Behavior and Human Process, 5o, 179 - 211 (1991).

Ajzen, I. (2002). Perceived behavioral control, self-efficacy, locus of control, and the theory of planned behavior. Journal of Applied Social Psychology, 32(4), 665-683.

Association of Certified Fraud Examiners. (2016). Report to the nations on occupational fraud and abuse. Austin: ACFE.

Bagustianto, R., \& Nurkholis. (2014). Faktor -faktor yang memengaruhi minat pegawai negeri sipil (PNS) untuk melakukan tindakan whistleblowing (studi pada PNS BPK RI). Jurnal Ilmiah Mahasiswa FEB Universitas Brawijaya, 3(1).

Chiu, R. K. (2002). Ethical judgment, locus of control, and whistleblowing intention: a case study of Mainland Chinese MBA students. Managerial Auditing Journal, $581-587$.

CNN Indonesia. (2016). ICW: Dinas Pendidikan rentan akan kasus korupsi. Retrieved from https:// www.cnnindonesia.com/nasional/ 20160517203120-20-131451/icwdinas-pendidikan-rentan-akan-kasus -korupsi

Crook, D. (2000). How to encourage whistleblowing. Journal of Financial Regulation and Compliance, 8(4).

Curtis, M. B., \& Taylor, E. Z. (2009). Whis- 
tleblowing in public accounting: influence of identity disclosure, situational context, and personal characteristics. Accounting and the Public Interest, 9(1), 191-220. doi: 10.2308/ api.2009.9.1.191.

Fitriyah, F. K., \& Nagara, T. K. (2017). The effect of professionalism, violation severity levels, and internal locus of control on whistleblowing intention. Review of Integrative Business \& Economics Research, 6, 133-154.

Ghani, N. A. (2013). Predicting whistleblowing in Malaysia: evidence from manufacturing companies. Dissertation in Curtin University School of Business.

Ghozali, I. (2016). Aplikasi analisis multivariate dengan Program IBM SPSS 23. Semarang: Badan Penerbit Universitas Diponegoro.

Handayani, T. (2009). Korupsi dan pembangunan pendidikan di Indonesia. Jurnal Kependudukan Indonesia, 4 (2). doi: 10.14203/jki.v4i2.183.

Hartono, T., \& Cahaya, F. R. (2017). Whistleblowing intention sebagai alat anti korupsi dalam institusi kepolisian. Akuisisi Jurnal Akuntansi, 13(2), 45-61. doi: 10.24127/ akuisisi.v13i2.156.g134.

Hsu, M. H., \& Chiu, C. M. (2004). Predicting electronic continuance with a decomposed theory of planned behaviour. Behaviour \& Information Technology, 23(5), 359-373. doi: 10.1080/ 01449290410001669969.

Indonesia Corruption Watch. (2010). Korupsi sekolah bersifat sistemik. Retrieved from https:// antikorupsi.org.
Jogiyanto. (2007). Sistem informasi keperilakuan. Yogyakarta: Andi.

Jakarta Newspaper. (2018). Mencegah korupsi di sekolah. Retrieved from http://www.koran-jakarta.com/ mencegah-korupsi-di-sekolah.

Lembaga Pengembangan and Pemberdayaan Kepala Sekolah Kementerian Pendidikan and Kebudayaan Indonesia. (2013). Bahan pembelajaran diklat calon kepala sekolah pengelolaan keuangan sekolah/madrasah. Karanganyar: LPPKS.

Lembaga Pengembangan and Pemberdayaan Kepala Sekolah Kementerian Pendidikan and Kebudayaan Indonesia. (2011). Pengertian dan fungsi ketatausahaan sekolah. Retrieved from http://lppks.kemdikbud.go.id.

MacNab, B. R., \& Worthley, R. (2008). Self efficacy as an intrapersonal predictor for internal whistleblowing: a US and Canada examination. Journal of Business Ethics, 79(4), 407 - 421. doi:10.1007/s10551-007-9407-3.

Ministry of National Education of the Republic of Indonesia. (2007). Regulation of the Minister of National Education of the Republic of Indonesia (Peraturan Menteri Pendidikan Nasional Republik Indonesia) Number 24 of 2007 on Standar-dized facilities and infrastructure of elementary schools/madrasah ibtidaiyah (SD/ MI), junior high school /madrasah tsanawiyah (SMP/MTs), and high school/madrasah aliyah (SMA/MA). Jakarta: Ministry of National Education of the Republic of Indonesia.

Mulyasa, E. (2009). Manajemen berbasis sekolah, konsep, strategi, dan implementasi. Bandung: Remaja Rosda- 
karya.

Orhan, U., \& Ozyer, K. (2016). I whistleblow as i am a university student: an investigation on the relationship between self-efficacy and whistleblowing. International Journal of Business Administration and Management Research, 2(1).

Park, H., \& Blenkinsopp, J. (2009). Whistleblowing as planned behavior a survey of South Korean police officers. Journal of Business Ethics, 85(4), 545 556.

Poespito, A. S. (2017). Determinan minat pegawai dalam melakukan tindakan whistleblowing. (Undergraduate $\mathrm{Pa}$ per). Faculty of Economics and Business, Brawijaya University.

Rothschild, J., \& Miethe, T. D. (1999). Whistle blower and management retaliation: the battle to control information about organization corruption. Work and Occupations, 26(1), 107-128. doi: 10.1177/ 073088849902600 1006.

Sama, H. K. (2014). Breaking the silence: efficacy of whistle blowing in public procurement. Proceedings of the First Middle East Conference on Global Business, Economics, Finance and Banking (ME14 DUBAI Conference), Dubai. Retrieved from http:// globalbizresearch.org/ Dubai_Conference/pdf/pdf/ D483.pdf.

Sekaran, U., \& Bougie, R. (2013). Research methods for business. New York: John Wiley \& Sons, Inc.

Sharif, Z. (2015). Intention towards whistleblowing among internal auditors in the U.K. (Doctoral Thesis). Business
School, Huddersfield University, England. Retrieved from http:// eprints.hud.ac.uk/id/eprint/28421.

Sugiyono. (2017). Metode penelitian kuantitatif, kualitatif and kombinasi (mixed methods). Bandung: Alfabeta.

Suryono, E., \& Chariri, A. (2016). Sikap, norma subjektif, dan intensi pegawai negeri sipil untuk mengadukan pelanggaran (whistleblowing). Jurnal Akuntansi dan Keuangan Indonesia, 13(1), 102-116. doi: 10.21002/ jaki.2016.06.

Tuanakotta, T. M. (2010). Akuntansi forensik \& audit investigatif. Jakarta: Salemba Empat.

Waytz, A., Dungan, J., \& Young, L. (2013). The whistleblower's dilemma and the fairness-loyalty tradeoff. Journal of Experimental Social Psychology, 49 (6) $1027-1033$.

Wei, L. C., Wang, K., \& Hsu, C. (2016). Intentions of employees to whistleblow information security policy violations in the organization. Asia Pacific Journal of Information Systems, 26(1), 163-188. doi: 10.14329/apjis.2016.26. 1.163

Winardi, R. D. (2013). The influence of individual and situational factors on lower-level civil servants' whistleblowing intention in Indonesia. Journal of Indonesian Economy and Business, 28(3), $361-376$.

Zakaria, M. (2015). Antecedent factors of whistleblowing in organizations. 7 th International Conference on Financial Criminology, Wadham College, Oxford, United Kingdom. 


\section{ACKNOWLEDGMENTS}

The authors would like to express gratitude to the Administrator of State Finance Administration \& Accountability Journal, Audit Board of the Republic of Indonesia (BPK) who have provided the opportunity to the author to publish this article and it is hoped that this article will benefit the readers. The authors would also like to acknowledge the Head of the National Unity and Politics Agency of Malang City, Head of Education Office of Malang City and Batu City, all the principals, vice principals, head of administration units, treasurers and financial administration employees of the high schools/vocational schools/ Islamic high schools of Malang City who have supported the author in collecting data so as to allow the study to be completed. Additionally, the authors would also like to thank all the people who have contributed their support to the successful completion of this study. 


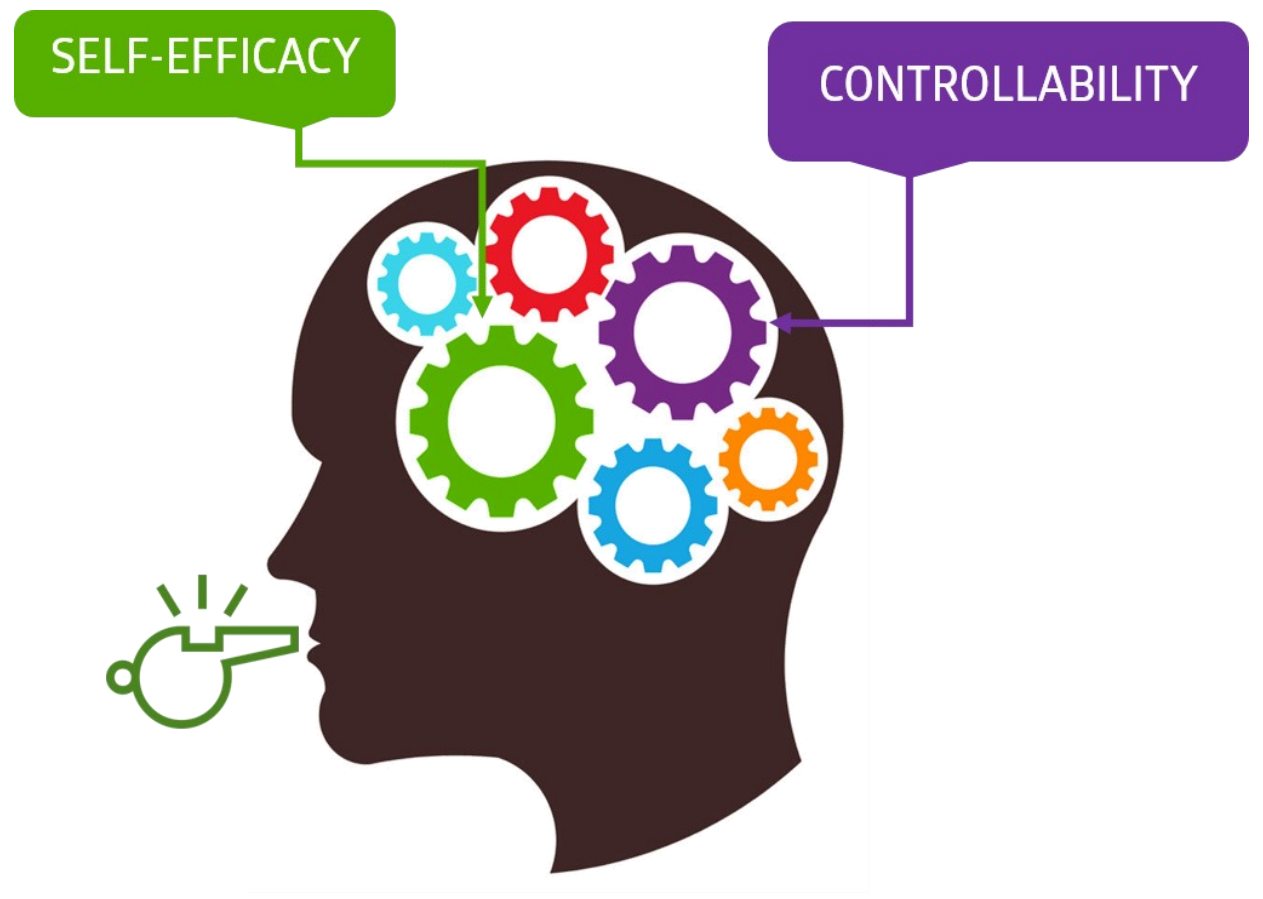

